\title{
Abundance and Habitat Selection of Breeding Scoters (Melanitta spp.) in Ontario's Hudson Bay Lowlands
}

\author{
Rodney W. Brook ${ }^{1,3}$, Kenneth F. Abraham ${ }^{1}$, Kevin R. Middel ${ }^{1}$, and R. Kenyon Ross ${ }^{2}$ \\ ${ }^{1}$ Wildlife Research and Development Section, Ontario Ministry of Natural Resources, Trent University, DNA Building, \\ 2140 East Bank Drive, Peterborough, Ontario K9J 7B8 Canada \\ ${ }^{2}$ Canadian Wildlife Service, Ontario Region, Environment Canada, 335 River Road, Ottawa, Ontario K1A 0H3 Canada; cur- \\ rent address: 1732 Dorset Drive, Ottawa, Ontario K1H 5T8 Canada \\ ${ }^{3}$ Corresponding author (email: rod.brook@ontario.ca)
}

Brook, Rodney W., Kenneth F. Abraham, Kevin R. Middel, and R. Kenyon Ross. 2012. Abundance and habitat selection of breeding scoters (Melanitta spp.) in Ontario's Hudson Bay Lowlands. Canadian Field-Naturalist 126(1): $20-27$.

Concern about declining populations of sea ducks counted on the wintering grounds prompted a survey of sea ducks on the breeding grounds in the Hudson Bay Lowlands of Ontario in spring 2009. We estimated densities of breeding scoters (Surf Scoter, Melanitta perspicillata, White-winged Scoter, M. fusca, and Black Scoter, M. americana) and found the average estimates of Surf Scoters $\left(\bar{x}=0.11\right.$ indicated pairs $\left./ \mathrm{km}^{2}\right)$ and Black Scoters $\left(\bar{x}=0.16\right.$ indicated pairs $\left./ \mathrm{km}^{2}\right)$ to be as high as some of the highest reported for North America. We also conducted a habitat association analysis using resource selection functions (RSF) for indicated pairs of all scoter species combined at a scale of $250 \mathrm{~m}$. Breeding pairs of scoters in the Hudson Bay Lowlands appear to have an affinity for smaller wetlands ( $\leq 100$ ha) disproportionate to what is available, also avoiding lakes (i.e., wetlands $>100$ ha). Pairs were also found in areas with less forest cover and fen area than was available. An estimate of the area under the curve of the receiver operating characteristic suggests that these habitat association models have some utility. Once tested and validated with surveys beyond the current study area, these models can be refined and used to predict habitat use by breeding pairs of scoters in the Hudson Bay Lowlands; this information will be particularly useful for population estimation and land use planning.

Key Words: Black Scoter, Melanitta americana, Surf Scoter, Melanitta perspicillata, White-winged Scoter, Melanitta fusca, density estimate, habitat selection, resource selection function, Hudson Bay Lowland, Hudson Bay Lowlands, Ontario.

Increasing concern about declines in winter indices of abundance of sea ducks (Anatidae: Mergini) has prompted researchers and agencies to devote more resources to their study and monitoring (Sea Duck Joint Venture $2007 *$, 2008). However, determining the causes of the apparent decline (Bordage and Savard 1995; Savard et al. 1998; Caithamer et al. 2000*) is a challenge because few breeding baseline indices exist for most sea duck species. The breeding densities and distribution of North American sea ducks have received relatively little attention compared to other waterfowl groups because most breed in remote locations, making monitoring and research relatively difficult.

The Hudson Plains ecozone (Ecological Stratification Working Group 1996) contains the third largest wetland complex in the world $\left(374,000 \mathrm{~km}^{2}\right)$ (Keddy and Fraser 2005) and the largest wetland complex in North America (Abraham and Keddy 2005; Riley 2011). Approximately $68 \%$ of the Hudson Plains ecozone is in Ontario. Ontario ecological land classification roughly equates the Hudson Plains ecozones, with the Hudson Bay Lowlands ecozone (Crins et al 2009*), and it is known to support many breeding waterfowl species (Thomas and Prevett 1982; Ross 1982; Cadman et al. 2007). Attempts to quantify densities of waterfowl other than geese have been limited (e.g., Ross 1987). Surveys for geese and many ducks are typically too early for species like scoters (Melanitta spp.) that breed late in the season, and such counts are not thought to produce an annually comparable index for them in other areas (Ross 1987).

The Hudson Bay Lowlands are known to be home to breeding scoters (Surf Scoter, Melanitta perspicillata, White-winged Scoter, M. fusca, and Black Scoter, $M$. americana), but the abundance of and habitat use by these three species are poorly documented (Ross 2007a, 2007b, 2007c, respectively). There are known concentrations of moulting scoters nearby in Hudson Bay and James Bay that suggest reasonably large local breeding populations (Ross 1994). The relative contribution of the Hudson Plains ecozone to the breeding populations of scoters and other sea ducks in the eastern half of North America is not known, but it may be considerable. Further, little is known about habitat selection for any of the three scoter species, and most accounts are simply descriptions of where the species were observed or a micro-habitat description of a nest observation (see Brown et al. 1997; Bordage and Savard 1995; Savard et al. 1998; but see Traylor et al. 2004).

In 2009, we conducted aerial surveys in a large study area centrally located in the Hudson Bay Lowlands to quantify the abundance of breeding sea ducks. The survey was timed to survey these species at nest initiation. We report densities of breeding scoters and quantify their habitat association using a resource selection function analysis. 


\section{Methods}

Surveys

In 2009, we established 10 transects of $100 \mathrm{~km}$ each within a study area of $10000 \mathrm{~km}^{2}$ (Figure 1). The area surveyed was $2 \%$ of the total study area. Observations were recorded from a Eurocopter A-Star B2 helicopter at $30 \mathrm{~m}$ above ground level. To help us assess the detection rate, we recorded observations as being between 0 and $50 \mathrm{~m}$ (inner band), >50 to $100 \mathrm{~m}$ (middle band), and >100 m (outer band). We compared the relative number of observations in each band (not a formal distance sampling method, however). For density calculations, observations within a perpendicular distance of up to $100 \mathrm{~m}$ from each side of the aircraft were used. The right side observer was RWB, the left side was KFA, and RKR was the middle observer, data recorder, and navigator. We flew at an average speed of $78 \mathrm{~km} / \mathrm{hr}$ and georeferenced each observation using a Garmin 296 GPS. Transects were flown on 7-10 June 2009 and timing was based on the personal experience of RKR and KFA using information from a previous survey (Ross 1987) and from another waterfowl survey flown in the same area earlier the same year by RWB.

We estimated the number of indicated pairs (IP) for scoters based on general guidelines for other species, as no specific guidelines have been published for scoters (e.g., Dzubin 1969; Gilliland et al. 2009*). For groups of four or fewer males, each male was counted as an indicated pair. Groups of five or more males were not considered to be locally breeding. Males were distinguished by plumage markings and general body colour for more distant birds. A lone female or a female with a male or a female together with a group of males was considered an indicated pair. We assumed that scoters were uniformly distributed throughout the study area, and we calculated an average density for each species on the transect survey area.

\section{Analysis}

Habitat analysis was performed using the 48 class Provincial Land Cover (PLC) dataset for Ontario (Spectranalysis Inc. 1997) as the principal habitat layer. The Provincial Land Cover was derived through supervised classification based on spectral reflectance analysis of Landsat Thematic Mapper (TM) imagery with $30 \mathrm{~m}$ resolution collected between 1986 and 1997. Although more recent landcover products are available and with fewer classes, this particular version was created with special emphasis on wildlife habitat mapping and wetland delineations for ecoregions 215 and 217 (Ecological Stratification Working Group 1996).

A resource selection function is any model that provides values proportional to the probability of use of a resource unit (Boyce et al. 2002). To estimate resource selection functions (RSF) (Manly et al 1993; Boyce et al. 2002) for scoters from observations of scoter indicated pairs, we overlaid the location of each presence/absence observation on the Provincial Land Cover dataset using ArcMap 9.3.1 (ESRI 2009*) to extract habitat data. To reduce the total number of variables for modelling, we combined some habitat types on the classified image that were similar (e.g., treed wetland, conifer swamp, and treed bog were combined under treed wetland; open fen and shrub rich fen were combined under fen; lichen rich bog and shrub rich bog were combined under bog).

We determined the proportion of each habitat type from the classified image at a spatial scale of $250 \mathrm{~m}$ (a circle with a radius of $250 \mathrm{~m}$ centered on each location where indicated pairs were recorded). The area of each site was approximately 20 ha. We did a parallel analysis at a $500 \mathrm{~m}$ scale as well, but found results to be so similar that we do not present them here. We calculated the proportion of each habitat type for each non-overlapping site where no indicated pairs were recorded as well. Locations where no indicated pairs were observed were randomly selected within the flown transect. Because almost all variables were expressed as a proportion of area, we transformed them using an arc sine transformation to help improve normality of errors (Sokal and Rohlf 1998). Wetlands were also identified as either water or deep water from the imagery, based on spectral reflectance (i.e., deep water was clear and dark, shallow water was light colored from sediment), and so we included a binary variable of deep water occurrence. Deep water is defined using reflectance only, so no depth boundaries are available.

Attempts to calculate resource selection functions for indicated pairs of any one species (e.g., Black Scoter) failed because total observations were too sparse for models to converge; therefore, we calculated resource selection functions for observations of all indicated pairs of scoter species combined. We used generalized logistic regression (PROC LOGISTIC: version 9.2, SAS Institute, Cary, N.C.) and proportion of habitat type data to model probability of indicated pairs being observed in various habitats by comparing sites where indicated pairs were observed to sites where no indicated pairs were observed.

We hypothesized that breeding scoters would have a stronger affinity for wetland habitats. We used a hierarchical process whereby we first tested the fit of candidate models composed of wetland habitat types only (Table 1). We selected the best fitting wetland model and used this model as the null model (or base model) on which to build subsequent candidate models using proportions of non-wetland habitat types. Wetland variables in the first analyses were scaled to the total of all wetland habitats, then rescaled for the second analysis to the total of all habitat variables (including wetland variables). All candidate models were constructed based on the authors' prior knowledge of scoter breeding habitat associations (e.g., Ross 2007a, 2007b, 2007c; Abraham et al. 2008), along with the use of summary statistics of the comparison of sites where indicated pairs were present/absent for each habitat type reported herein. 


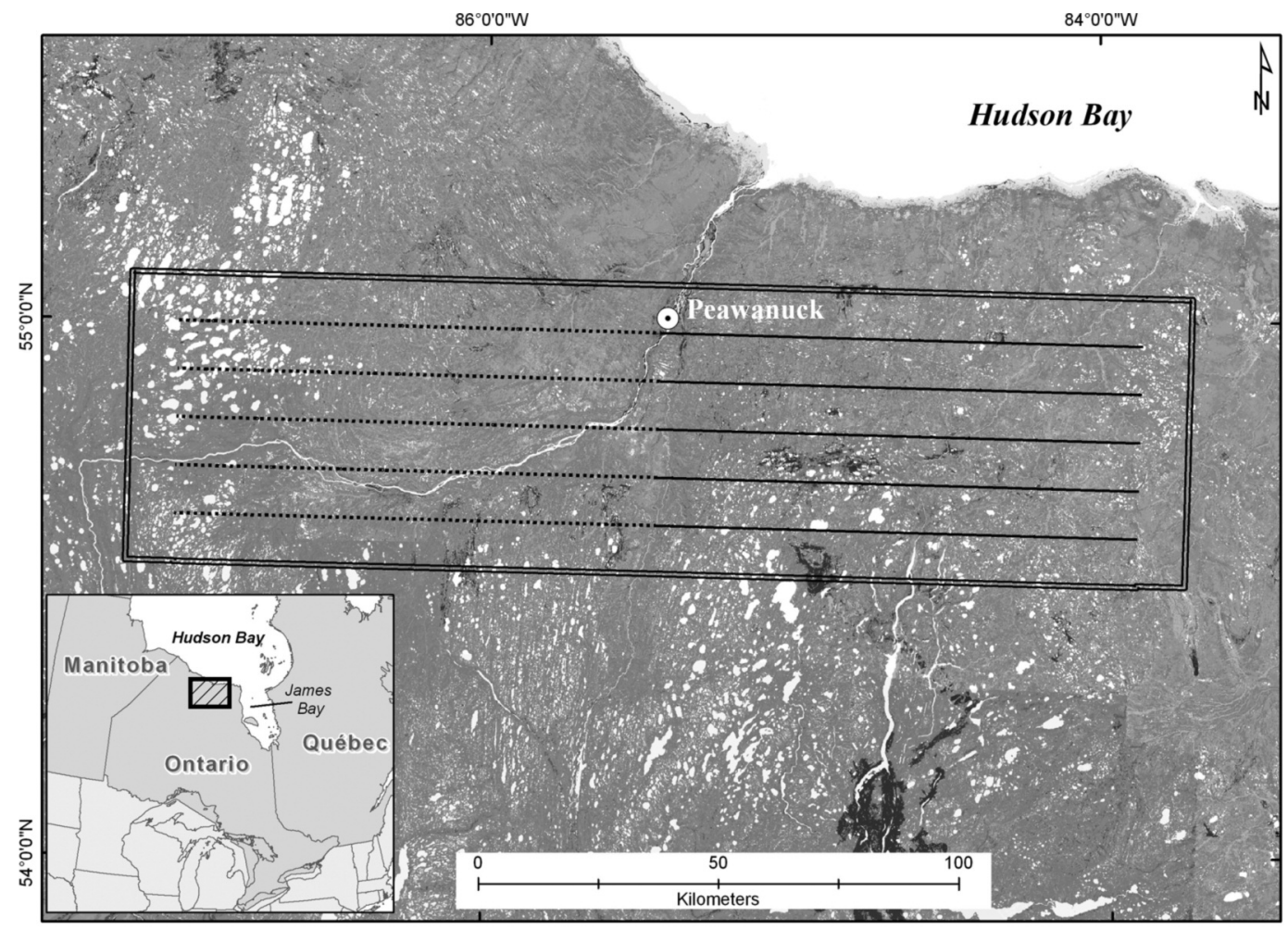

FIGURE 1. Location of the transects $100 \mathrm{~km}$ in length used to survey breeding Black Scoters, Surf Scoters, and White-winged Scoters in the Hudson Bay Lowlands, Ontario, 7-10 June 2009. Dashed and solid lines indicate separate transects flown.

We used Akaike's Information Criterion $\left(\mathrm{AIC}_{c}\right.$ : Akaike 1973) corrected for small sample size (Burnham and Anderson 1998) to select among candidate models, and we estimated the area under the curve for the receiver operating characteristic (ROC) to assess model performance (Cumming 2000). Area under the receiver operating characteristic curve is considered an index of whether the model can reliably classify a site, with a value of 0.5 being a worthless model and 1.0 being a perfect model. We present all models $\leq 4$ $\Delta \mathrm{AIC}_{c}$ units (Burnham and Anderson 1998). The fit of each global model was determined by a likelihood ratio test (test of the global null hypothesis that $\beta=0$; $\alpha=0.05$ ). We used an ANOVA to test for a difference in the number of observations between observation bands.

\section{Results}

Scoter average density

We compared the number of observations in each of the three observation bands we established but found no statistical difference in the number of indicated pairs of scoters observed $\left(F_{2,55}=0.76, P=0.47\right.$; inner band $\bar{x}=2.06, \mathrm{SE}=0.337 ;$ middle band $\bar{x}=1.89, \mathrm{SE}=$ 0.351 ; outer band $\bar{x}=2.48, \mathrm{SE}=0.371$ ).
There were 59 observations of scoter indicated pairs. Black Scoters were the most abundant of the three scoter species counted during the breeding pair survey $\left(\bar{x}=0.16\right.$ indicated pairs $\left./ \mathrm{km}^{2}, \mathrm{SE}=0.036\right)$. Surf Scoters were next most abundant $(\bar{x}=0.11$ indicated pairs/ $\left.\mathrm{km}^{2}, \mathrm{SE}=0.035\right)$ and White-winged Scoter were least abundant $\left(\bar{x}=0.06\right.$ indicated pairs $\left./ \mathrm{km}^{2}, \mathrm{SE}=0.023\right)$. Black Scoter indicated pairs made up $45.8 \%$ of all scoter observations, Surf Scoters made up 32.2\%, White-wing Scoters $6.8 \%$, and unidentified scoter species $15.2 \%$. We combined all scoter observations for habitat analyses $\left(\bar{x}=0.35\right.$ indicated pairs $/ \mathrm{km}^{2}$, $\mathrm{SE}=0.071)$ because indicated pair data were too sparse for modelling individual species.

\section{Site characteristic comparison}

Comparison of the average area of each habitat type associated with sites where indicated pairs were observed and sites where no indicated pairs were observed indicates that sites where indicated pairs were present have more area of the small wetlands ( $\leq 100 \mathrm{ha}$; Figure 2). Sites where an indicated pair was observed had, on average, $18.5 \%$ small wetland landcover, whereas those with no indicated pairs observed had only $5.6 \%$ small wetland landcover (Figure 3). Sites where indi- 
TABLE 1. Definitions of predictor variables used to build candidate models to estimate resource selection functions for indicated pairs of Black Scoters, Surf Scoters, and White-winged Scoters combined, surveyed in the Hudson Bay Lowlands, Ontario, 7-10 June 2009. All variables were calculated as a proportion of area.

\begin{tabular}{ll}
\hline \hline Variable & Description $\left(\operatorname{area}=\mathrm{m}^{2}\right)$ \\
\hline Wetlands $\leq 5$ ha & Area of wetlands between 1 and 5 ha \\
Wetlands $>5$ to $\leq 100$ ha & Area of wetlands between 5 and 100 ha \\
Wetlands $\leq 100$ ha & Area of wetlands between 1 and 100 ha \\
Wetlands $>100$ ha & Area of wetlands $>100$ ha \\
Deep water & Area of water indicated as deep water on imagery based on spectral reflectance (i.e., deep water \\
& was clear and dark, shallow water was light colored from sediment). No depth boundaries are \\
Bog & available. \\
Fen & Area of bog, including lichen rich bog and shrub rich bog \\
Treed wetland & Area of fen, including shrub rich fen and open fen \\
Fen pools & Area of trees growing in wet habitats, including conifer swamp and treed bog \\
\hline \hline
\end{tabular}

cated pairs were present have less area of the large wetlands (>100 ha) (sites where an indicated pair was observed had only $0.7 \%$ large wetland landcover, whereas sites where no indicated pairs were observed had $2.7 \%$ large wetland landcover). Also, the average site where indicated pairs were observed had less coverage of fen than sites where no indicated pairs were observed (sites where an indicated pair was observed had $22.6 \%$ of fen landcover, whereas sites where no indicated pairs were observed had $30.3 \%$ fen landcover). Also, sites where indicated pairs were observed had less treed wetland coverage (sites where indicated pairs were observed had $12.2 \%$ treed wetland landcover, whereas sites where no indicated pairs were observed had $18.4 \%$ treed wetland landcover).

\section{Wetland resource selection functions}

We compared 59 sites where indicated pairs were present to 1544 sites where indicated pairs were absent using nine candidate models. The global model fit the data $\left(\chi^{2}=33.62, P<0.0001\right)$. The most parsimonious model (Table 2, intercept $\beta=-4.49, \mathrm{SE}=0.505$ ) included the proportion of wetlands $\leq 100$ ha $(\beta=1.29$, $\mathrm{SE}=0.308)$ and the occurrence of deep water $(\beta=$ $-0.43, \mathrm{SE}=0.228)$; however, the addition of the deep water binomial variable was uninformative (i.e., $95 \%$ confidence limits of $\beta$ coefficients included 0$)$. Therefore, we included the proportion of the variable wetlands $\leq 100$ ha in subsequent habitat selection candidate models and considered the model with this variable alone $(\beta=1.30, \mathrm{SE}=0.307$, intercept $\beta=-4.88$, $\mathrm{SE}=0.462$ ) to be the null model in the assessment of candidate models assessing non-wetland variables.

\section{Habitat resource selection functions}

We assessed four candidate models. The global model fit the data $\left(\chi^{2}=43.94, P<0.0001\right)$ and was the most parsimonious. All variables in the most parsimonious model were informative, with the exception of area of fen (intercept $=-2.89, \mathrm{SE}=0.299$; wetlands $\leq 100$ ha $\beta=3.22, \mathrm{SE}=0.629$; treed wetland $\beta=-2.45$, $\mathrm{SE}=0.949$; and fen $\beta=-1.27, \mathrm{SE}=0.684)$. We considered one other model that was similar to the most parsimonious but did not include the variable area of fen. The model averaged coefficients were similar to those of the most parsimonious model (intercept = $-3.04, \mathrm{SE}=0.274$; wetlands $\leq 100$ ha $\beta=3.36, \mathrm{SE}=$ 0.619 ; and treed wetland $\beta=-2.15, \mathrm{SE}=0.949)$. The most parsimonious model had an area under the receiver operating characteristic curve of 0.77 (95\% CL = $0.72-0.82)$.

\section{Discussion}

Although we made assumptions about high detection rates of scoter indicated pairs during aerial surveys and the similarity of the habitat selected by the three species, we feel we introduced negligible bias in the analysis results. Sea ducks are known to be highly visible during aerial breeding pair surveys (Ross 1987) and so we assumed that areas where scoter indicated pairs were not observed during our survey were not being used by breeding scoters during the survey. Finding no statistical difference in the number of observations per observation band during the survey provides support for our assumption. We believe that grouping the species was justified, as there is evidence that they have similar breeding habitat requirements in the Hudson Bay Lowlands (Ross 2007a, 2007b, 2007c; Abraham et al. 2008). Both the Black Scoter and the Surf Scoter use relatively small wetlands $(<10 \mathrm{ha})$ and tend to avoid large lakes for breeding (Bordage and Savard 1995; Savard et al. 1998). The White-winged Scoter uses larger wetlands ( $>50$ ha) (Brown et al. 1997; Traylor et al. 2004), preferring to nest on islands when in prairie habitat. However, breeding habitat in the Hudson Plains ecozone for these species has been described based on only scant evidence, with the exception of the Black Scoter, and each species has a relatively wide (continental) breeding range, making it difficult to compare the published descriptions of breeding sites for these species.

Ross (unpublished data) estimated a Black Scoter breeding density of 0.026 indicated pairs $/ \mathrm{km}^{2}$ with a peak of 0.08 pairs $/ \mathrm{km}^{2}$ in 1987 and 1988 in the general vicinity of our 2009 survey. The peak was only half 


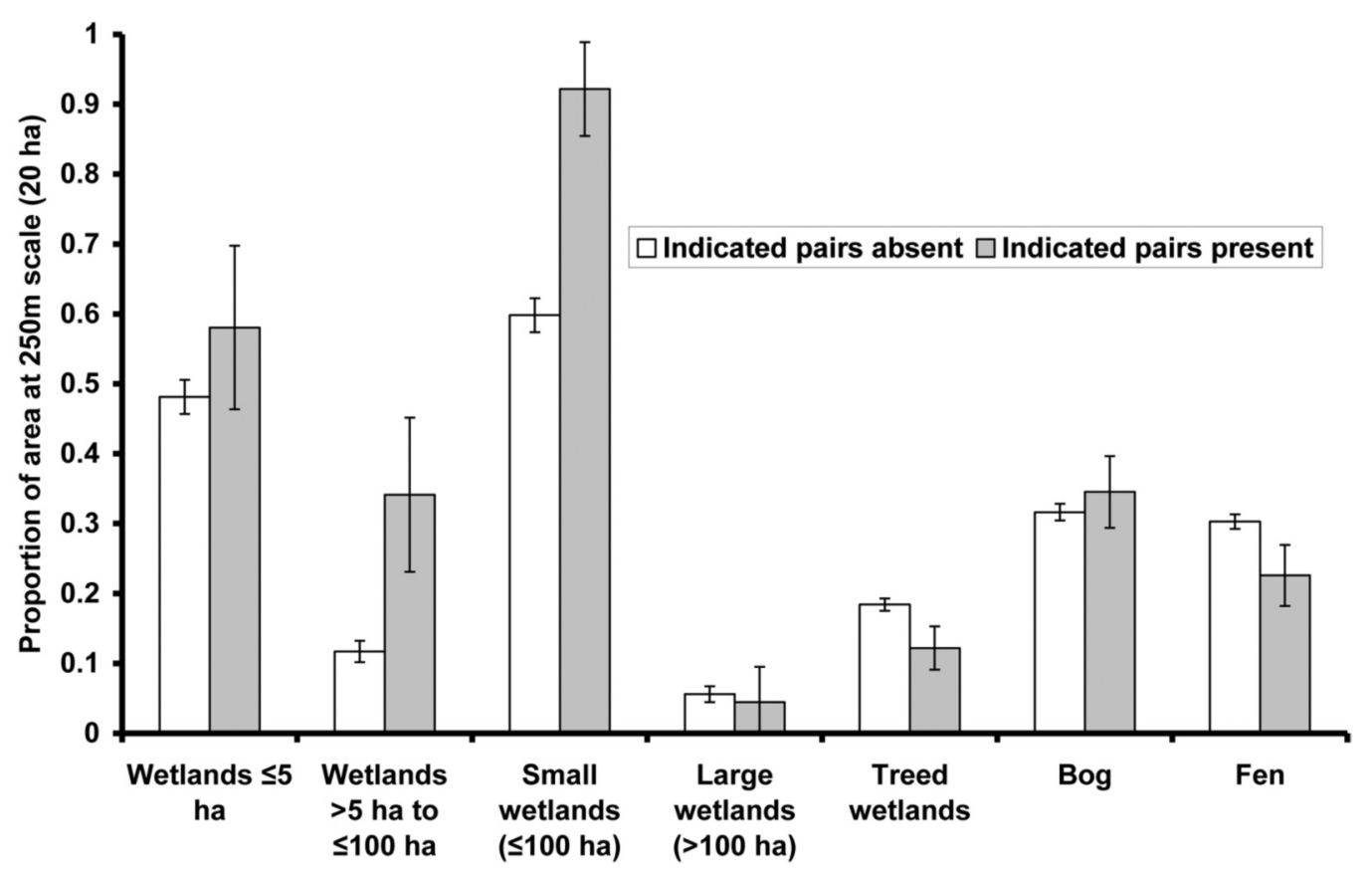

FIGURE 2. Mean proportion of habitat types. Wetland proportions are based on the total wetland habitat only. Proportions of non-wetland habitats are based on total of all habitat types. "Indicated pairs present" indicates area of habitat for sites where indicated pairs of Black Scoters, Surf Scoters, and White-winged Scoters combined were observed during aerial surveys of the Hudson Bay Lowlands, Ontario, 7-10 June 2009.

the density that we estimated $\left(0.16, \mathrm{SE}=0.036 / \mathrm{km}^{2}\right)$, likely because the 1987 and 1988 surveys were not timed for scoters (they were conducted earlier in the season and were better suited to observe dabbling ducks). Our Black Scoter densities are comparable to the estimate of 0.12 indicated pairs $/ \mathrm{km}^{2}$ for the highest density areas of northern Quebec (Savard and Lamothe 1991).

Likewise, our estimated densities of indicated pairs of Surf Scoters $\left(0.11 / \mathrm{km}^{2}\right)$ are double the peak estimate of 0.05 pairs $/ \mathrm{km}^{2}$ of Ross (1987) and are comparable with estimates of $0.10 / \mathrm{km}^{2}$ for the highest density areas of northern Quebec (Gauthier and Aubry 1996). Savard and Lamothe (1991) reported Surf Scoter brood densities as high as $0.05 / \mathrm{km}^{2}$ in northern Quebec (this would be an underestimate of breeding pairs, as not all nests are successful).

Our estimated densities of indicated pairs of Whitewinged Scoter were the lowest of the three species that we observed $\left(0.06 / \mathrm{km}^{2}\right)$ and were similar to the estimated peak abundance of 0.042 indicated pairs $/ \mathrm{km}^{2}$ reported by Ross (1987) from the area to the immediate west of our study area. Unlike the estimated densities for the two other scoter species, this estimate was much lower than densities observed inland from the James Bay coast in Quebec of 0.80 pairs $/ \mathrm{km}^{2}$ (Gauthier and Aubry 1996).
We report results for the $250 \mathrm{~m}$ spatial scale only, but we found that selection for wetland habitat was similar between the two scales we analyzed. At the $250 \mathrm{~m}$ scale (20 ha), breeding scoters were observed at sites with disproportionately more area of small wetlands ( $\leq 100 \mathrm{ha})$. When we investigated models that contained only the variable wetlands $\leq 5$ ha, the coefficient was uninformative, suggesting there was no significant preference for sites with these smallest wetlands. There was also no indication that there was selection for areas with deep water or lakes (i.e., wetlands $>100$ ha), as these variables produced a negative coefficient but were uninformative.

The dominant forest cover in the study area was treed wetland (Table 1). Other dry forest cover types made up less than $2 \%$ of the study area. Treed wetland included conifer swamp with dominant cover species of Tamarack (Larix laricina) and Black Spruce (Picea mariana) and an understory dominated by willow ( $\mathrm{Sal}$ $i x$ spp.). Treed bog (also included in treed wetland) was similarly dominated by Black Spruce with an understory dominated by Leatherleaf (Chamaedaphne calyculata) and Common Labrador Tea (Rhododendron groenlandicum). Treed wetland appeared to be avoided by breeding scoters, as indicated by the negative coefficient we detected. Treed wetland was informative only after model averaging. Fen was com- 

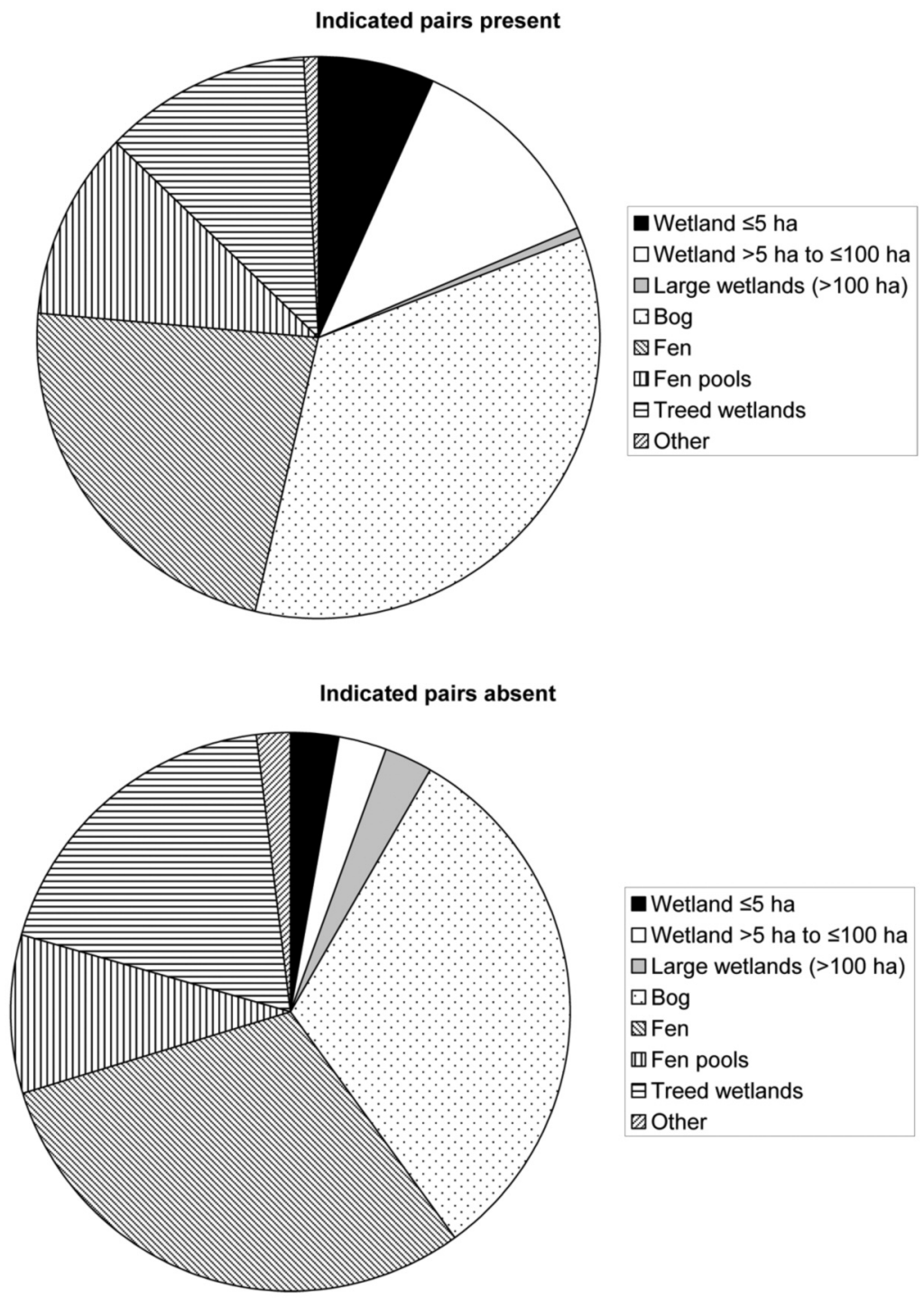

FIGURE 3. Pie charts showing average proportion of each habitat type at sites where at least one indicated pair of Black Scoters, Surf Scoters, and White-winged Scoters combined were observed (Indicated pairs present) or for sites where none were observed (Indicated pairs absent) during aerial surveys of the Hudson Bay Lowlands, Ontario, 7-10 June 2009.

posed of open fen habitat dominated by sedges (Carex spp.) and grasses/rushes (Scirpus spp.) and shrub rich fen dominated by Tamarack, willow, and dwarf birch (Betula spp.). There was also a negative correlation with fen, suggesting scoter indicated pairs were observed in sites with less fen area. The habitat selected appears to be less fen and forest area in favor of more area of small wetlands ( $\leq 100 \mathrm{ha})$.

We estimated model performance of the resource selection functions using area under the curve of the receiver operating characteristic. We considered mod- els with values ranging between 0.7 and 0.9 as having useful application (Manel at al. 2001; Boyce et al. 2002). The area under the curve for the most parsimonious model suggests useful application, but its performance was not stellar (i.e., low end of the useful range).

Our surveys provide evidence of some of the highest densities of Black Scoter and Surf Scoter observed in northern Canada. Delineating the area over which these densities are applicable is important for understanding the overall contribution of the Hudson Bay 
TABLE 2. Model selection results. Candidate models were fit to data describing presence in wetland habitats of indicated pairs of Black Scoters, Surf Scoters, and White-winged Scoters combined, surveyed in the Hudson Bay Lowlands, Ontario, 7-10 June 2009 (i.e., models included only wetland variables). Table includes only models $\leq 4 \Delta \mathrm{AIC}_{c}$ units. $\Delta \mathrm{AIC}_{c}=$ difference between Akaike's Information Criterion corrected for small sample size for most parsimonious model and the model in question; cumulative $w=$ cumulative model weight (model weight is an indication of relative model importance); $\mathrm{K}=$ number of estimable parameters; $-2 \mathrm{LL}=-2 *$ the model log likelihood.

\begin{tabular}{|c|c|c|c|c|}
\hline Model & $\Delta \mathrm{AIC}_{c}$ & Cumulative $w$ & $\mathrm{~K}$ & $-2 \mathrm{LL}$ \\
\hline \multicolumn{5}{|c|}{ Presence of indicated pairs in wetland habitat } \\
\hline Wetlands $\leq 100$ ha + deep water & 0.000 & 0.574 & 3 & 471.83 \\
\hline Wetlands $\leq 100$ ha & 0.603 & 0.998 & 2 & 474.73 \\
\hline \multicolumn{5}{|c|}{ Presence of indicated pairs in habitats ${ }^{1}$} \\
\hline Treed wetland + fen & 0.000 & 0.582 & 4 & 461.51 \\
\hline Treed wetland & 1.507 & 0.855 & 3 & 465.31 \\
\hline
\end{tabular}

${ }^{1}$ All models contain the variable wetlands $\leq 100$ ha.

Lowlands to the continental population of each species. If the densities are similar elsewhere in the vast Lowlands, it indicates a high conservation value for this remote and pristine area and suggests it may be a major source of the moulting scoters in nearby James Bay and Hudson Bay. Once we have tested and validated our resource selection functions outside our study area to determine their overall utility, we will use them to help refine distribution estimates. These estimates and models will be useful for land use and waterfowl conservation planning application in the entire Hudson Bay Lowland ecozone, as there are currently no predictive habitat models for breeding scoters in northern Canada.

\section{Acknowledgements}

We thank the Sea Duck Joint Venture for funding. We also thank pilot Andrew Fitch for his expert flying and Mike Hunter for radio operation. We thank two anonymous reviewers for their helpful comments.

Documents Cited (marked * in text)

Caithamer, D. F., M. Otto, P. I. Padding, J. R. Sauer, and G. H. Haas. 2000. Sea ducks in the Atlantic Flyway: population status and a review of special hunting seasons. Unpublished report. U.S Fish and Wildlife Service, Laurel, Maryland.

Crins, W. J., P. A. Gray, P. W. C. Uhlig, and M. C. Webster. 2009. The ecosystems of Ontario, Part 1: ecozones and ecoregions. SIB Report TER IMA TR 01. Ontario Ministry of Natural Resources, Inventory, Monitoring and Assessment Section. Peterborough, Ontario.

ESRI (Environmental Systems Resource Institute). 2009. ArcMap Release 9.3.1. Environmental Systems Research Institute, Redlands, California.

Gilleland, S., C. Lepage, J-P. L. Savard, D. Bordage, G. J. Robertson, and E. Reid. 2009. SDJV Project \#115: Developmental surveys for breeding scoters in eastern North America. http://seaduckjv.org/studies/pro3/pr115.pdf. (Accessed 15 July 2012.)

Sea Duck Joint Venture. 2007. Recommendations for monitoring distribution, abundance and trends for North American sea ducks. December 2007. U.S. Fish and Wildlife
Service, Anchorage, Alaska, and Canadian Wildlife Service, Sackville, New Brunswick. http://seaduckjv.org/mon itor.htm. (Accessed 19 December 2011.)

\section{Literature Cited}

Abraham, K. F., and C. E. Keddy. 2005. The Hudson Bay Lowland: a unique wetland legacy. (Chapter 4). Pages 118148 in The World's Largest Wetlands: Ecology and Conservation. Edited by L. H. Fraser and P. A. Keddy. Cambridge University Press, Cambridge.

Abraham, K. F., D. M. Filliter, and D. A. Sutherland. 2008. First documentation of Black Scoter breeding in Ontario. Ontario Birds 26: 108-118.

Akaike, H. 1973. Information theory as an extension of the maximum likelihood principle. Pages 267-281 in Second International Symposium on Information Theory. Edited by B. N. Petrov and F. Csaki. Akademiai Kiado, Budapest, Hungary.

Bordage, D., and J-P. L. Savard. 1995. Black Scoter (Melanitta nigra). In The Birds of North America, No. 177. Edited by A. Poole and F. Gill. Academy of Natural Sciences, Philadelphia, and American Ornithologists' Union, Washington, D.C.

Boyce, M. S., P. R. Vernier, S. E. Nielsen, and F. K. A. Schmiegelow. 2002. Evaluating resource selection functions. Ecological Modelling 157: 281-300.

Brown, P. W., and L. H. Fredrickson. 1997. White-winged Scoter (Melanitta fusca). In The Birds of North America, No. 274. Edited by A. Poole and F. Gill. Academy of Natural Sciences, Philadelphia, and American Ornithologists' Union, Washington, D.C.

Burnham, K. P., and D. R. Anderson. 1998. Model Selection and Inference: A Practical Information-Theoretic Approach. Springer-Verlag, New York.

Cadman, M. D., D. A. Sutherland, G. C. Beck, D. LePage, and A. R. Couturier (Editors). 2007. Atlas of the Breeding Birds of Ontario 2001-2005. Bird Studies Canada, Environment Canada, Ontario Field Ornithologists, Ontario Ministry of Natural Resources, and Ontario Nature, Toronto.

Cumming, G. S. 2000. Using between-model comparisons to fine-tune linear models of species ranges. Journal of Biogeography 27: 441-455.

Dzubin, A. 1969. Assessing breeding populations of ducks by ground counts. Pages 178-237 in Saskatoon Wetlands 
Seminar: Transactions of a seminar on small water areas in the prairie pothole region, held February 20 to 22, 1967, to mark the opening of the Prairie Migratory Bird Research Centre in Saskatoon, Saskatchewan. Canadian Wildlife Service Report Series, Number 6.

Ecological Stratification Working Group. 1996. A National Ecological Framework for Canada. Centre for Land and Biological Resources Research, Research Branch, Agriculture and Agri-Food Canada, and State of the Environment Directorate, Environment Conservation Service, Environment Canada, Ottawa. http://sis.agr.gc.ca/cansis/ publications/ecostrat/intro.html\#report and http://ecozones .ca/english/.

Gauthier, J., and Y. E. Aubry. 1996. The Breeding Birds of Québec: Atlas of the Breeding Birds of Southern Québec. Association québécoise des groupes d'ornithologues; Province of Quebec Society for the Protection of Birds; and Canadian Wildlife Service, Environment Canada, Quebec Region, Montreal.

Keddy, P. A., and L. H. Fraser. 2005. Introduction: big is beautiful. Pages 1-10 in The World's Largest Wetlands: Ecology and Conservation. Edited by L. H. Fraser, and P. A. Keddy. Cambridge University Press, Cambridge, U.K.

Manel S., H. Ceri Williams, and S. J. Ormerod. 2001. Evaluating presence/absence models in ecology: the need to account for prevalence. Journal of Applied Ecology 38: 921-931.

Manly, B. F. J., L. L. McDonald, and D. L. Thomas. 1993. Resource Selection by Animals: Statistical Design and Analysis for Field Studies. Chapman \& Hall, London.

Riley, J. L. 2011. Wetlands of the Hudson Bay Lowland: An Ontario Overview. Nature Conservancy of Canada, Toronto.

Ross, R. K. 1982. Duck distribution along the James and Hudson Bay coasts of Ontario. Le Naturaliste canadien 109: 927-932.

Ross, R. K. 1987. Interim report on waterfowl breeding pair surveys in northern Ontario. Canadian Wildlife Service Progress Note 168.

Ross, R. K. 1994. The Black Scoter in northern Ontario. Ontario Birds 12: 1-7.

Ross, R. K. 2007a. Surf Scoter. Pages 100-101 in Atlas of the Breeding Birds of Ontario 2001-2005. Edited by M. D. Cadman, D. A. Sutherland, G. C. Beck, D. LePage, and
A. R. Couturier. Bird Studies Canada, Environment Canada, Ontario Field Ornithologists, Ontario Ministry of Natural Resources, and Ontario Nature, Toronto.

Ross, R. K. 2007b. White-winged Scoter. Pages 102-103 in Atlas of the Breeding Birds of Ontario 2001-2005. Edited by M. D.Cadman, D. A. Sutherland, G. C. Beck, D. LePage, and A. R. Couturier. Bird Studies Canada, Environment Canada, Ontario Field Ornithologists, Ontario Ministry of Natural Resources, and Ontario Nature, Toronto.

Ross, R. K. 2007c. Black Scoter. Pages 104-105 in Atlas of the Breeding Birds of Ontario 2001-2005. Edited by M. D. Cadman, D. A. Sutherland, G. C. Beck, D. LePage, and A. R. Couturier. Bird Studies Canada, Environment Canada, Ontario Field Ornithologists, Ontario Ministry of Natural Resources, and Ontario Nature, Toronto.

Savard, J.-P. L., and P. Lamothe. 1991. Distribution, abundance, and aspects of breeding ecology of Black Scoters, Melanitta nigra, and Surf Scoters, $M$. perpicillata, in northern Québec. Canadian Field-Naturalist 105: 488-496.

Savard, J. L., D. Bordage, and A. Reed. 1998. Surf Scoter (Melanitta perspicillata). In The Birds of North America, No. 363. Edited by A. Poole and F. Gill. Academy of Natural Sciences, Philadelphia, and American Ornithologists' Union, Washington, D.C.

Sea Duck Joint Venture. 2008. Sea Duck Joint Venture Strategic Plan 2008-2012. U.S. Fish and Wildlife Service, Anchorage, Alaska, and Canadian Wildlife Service, Sackville, New Brunswick.

Sokal, R. R., and F. J. Rohlf. 1998. Biometry: The Principles and Practice of Statistics in Biological Research. Third edition. W. H. Freeman and Co., New York.

Spectranalysis Inc. 1997. User manual on the Ontario provincial land cover data base with recommendations for data base management. Spectranalysis Inc., Oakville, Ontario.

Thomas, V. G., and J. P. Prevett. 1982. The roles of the James and Hudson Bay lowland in the annual cycle of geese. Le Naturaliste Canadien 109: 913-925.

Traylor, J. J., R. T. Alisauskas, and F. P. Kehoe. 2004. Nesting ecology of White-Winged Scoters (Melanitta fusca deglandi) at Redberry Lake, Saskatchewan. The Auk 121: 950-962.

Received 5 January 2012

Accepted 30 June 2012 